\title{
Pharmacological and non-pharmacological management of burning mouth syndrome: A systematic review
}

\section{Leczenie farmakologiczne i niefarmakologiczne zespołu pieczenia jamy ustnej - przegląd piśmiennictwa}

\author{
Ayman Antoun Reyad ${ }^{1, A, B, D, E}$, Raafat Mishriky ${ }^{2, A, C, D}$, Eriny Girgis ${ }^{3, A, C, D}$ \\ ${ }^{1}$ School of Pharmacy, University of Wolverhampton, UK \\ ${ }^{2}$ Old Age Psychiatry, Birmingham and Solihull Mental Health NHS Foundation Trust, Birmingham, UK \\ ${ }^{3}$ Community Dental Service, Coventry and Warwickshire Partnership NHS Trust, Coventry, UK \\ A - research concept and design; $\mathrm{B}$ - collection and/or assembly of data; $\mathrm{C}$ - data analysis and interpretation; \\ $D$ - writing the article; $E$ - critical revision of the article; $F$ - final approval of the article
}

Address for correspondence

Ayman Antoun Reyad

E-mail: a.antounreyad@wlv.ac.uk

Funding sources

None declared

Conflict of interest

None declared

Received on December 4, 2019

Reviewed on April 19, 2020

Accepted on April 23, 2020

Published online on September 30, 2020

Cite as

Antoun Reyad A, Mishriky R, Girgis E. Pharmacological and nonpharmacological management of burning mouth syndrome: A systematic review. Dent Med Probl. 2020;57(3):295-304. doi:10.17219/dmp/120991

DOI

$10.17219 / \mathrm{dmp} / 120991$

Copyright

๑ 2020 by Wroclaw Medical University

This is an article distributed under the terms of the

Creative Commons Attribution 3.0 Unported License (CC BY 3.0)

(https://creativecommons.org/licenses/by/3.0/).

\begin{abstract}
Burning mouth syndrome (BMS) is idiopathic chronic oral pain, associated with depression, anxiety and pain symptoms. The BMS symptoms include a burning sensation in the tongue and/or other oral mucosa with no underlying medical or dental reasons. As many BMS patients suffer from psychiatric comorbidities, several psychotropic drugs are included in the management of BMS, reducing the complaint, while managing anxiety, depression and pain disorders.

In this review, a search of the published literature regarding the management of BMS was conducted. We discuss the BMS etiology, clinically associated symptoms and available treatment options. The current evidence supports some BMS interventions, including alpha-lipoic acid (ALA), clonazepam, capsaicin, and low-level laser therapy (LLLT); however, there is a lack of robust scientific evidence, and large-scale clinical trials with long follow-up periods are needed to establish the role of these BMS management options. This knowledge could raise the awareness of dentists, psychiatrists and general practitioners about these challenges and the available kinds of treatment to improve multidisciplinary management for better health outcomes.
\end{abstract}

Key words: burning mouth syndrome, neuropathic pain, orofacial pain, clonazepam, oral conditions

Słowa kluczowe: zespół pieczenia jamy ustnej, ból neuropatyczny, ból twarzoczaszki, klonazepam, warunki w jamie ustnej 


\section{Introduction}

Burning mouth syndrome (BMS) is oral dysesthesia characterized by a burning sensation in the tongue and/or other oral mucosa. It is associated with dry mouth and taste changes in the absence of clinical/laboratory findings or underlying medical or dental reasons, and it can be debilitating in some patients. ${ }^{1-3}$ Burning mouth syndrome is a painful cranial neuropathy, similar to trigeminal neuralgia, ${ }^{4}$ with mostly unknown etiology. As described by the international classification of headache disorders, BMS recurs daily for more than $2 \mathrm{~h}$ /day over more than 3 months without clinically evident causative lesions; the pain is usually bilateral with fluctuating intensity. ${ }^{5}$ The syndrome can also lead to sleep disturbances, especially in the elderly. ${ }^{6}$

Burning mouth syndrome is commonly associated with depression and anxiety. ${ }^{7}$ It has a prevalence of $0.7-5 \%$ and appears to be more frequent in females, ${ }^{8}$ especially in post-menopausal women, where its prevalence is $12-18 \% .{ }^{9}$ Females report more paresthesia, oral mucosal pain, dysgeusia and xerostomia, while taste changes are less common in males. ${ }^{10}$

Burning mouth syndrome is common in psychiatric patients; there are reports that it affects up to $20 \%$ of the older hospitalized psychiatric patients ${ }^{11-13}$ and $10-20 \%$ of elderly outpatients. ${ }^{14}$ It could be associated with oral or systemic abnormalities, such as changes in hormone levels, infections, nutritional disturbances, denturerelated lesions, and pharmacological treatment. ${ }^{15}$ The BMS characteristics include changes in the mucosal blood flow. ${ }^{16}$

Burning mouth syndrome has been described as a psychosomatic disorder predisposed by psychological stress or neuropathic pain, affecting the peripheral and central nervous system in the trigeminal pathways, ${ }^{3}$ the prefrontal cortex and the hippocampus. ${ }^{17}$ Patients with BMS process thermal stimulation differently, with changes in tactile sensory functions, including a lower threshold for cold detection, while warmth, heat and pain detection thresholds are higher. ${ }^{18-20}$

Immune and endocrine functions are also involved in BMS; a lower level of plasma adrenaline, a low level of $\mathrm{CD}^{(+)}$cells and a high $\mathrm{CD} 4^{(+)} / \mathrm{CD} 8^{(+)}$ratio represent a suppressed immune system. ${ }^{21}$ A significant increase in the genetic polymorphisms associated with interleukin- $1 \beta$ (IL-1 $\beta$ ) has also been suggested. ${ }^{22}$

Changes in scores on psychiatric assessment scales have been identified. With the Temperament and Character Inventory(TCI), BMS patients have lower novelty-seeking scores and self-directedness scores, while their harmavoidance scores are higher. ${ }^{23}$ A Visual Analog Scale (VAS) study supported higher frequencies of depression, anxiety and cancer phobia in BMS patients. ${ }^{24}$ This is reflected in the F3 classification of BMS as a mood/affective disorder. ${ }^{25}$
Risk factors for developing BMS include stroke, a low level of education, depression, life events, anxiety, personality disorders, the excessive use of hexetidine mouthwashes, and vitamin deficiency. ${ }^{26,27}$ Burning mouth syndrome is common in Parkinson's disease, characterized by dopamine dysregulation, especially in the nigrostriatal dopaminergic pathway, as confirmed by positron emission tomography (PET). ${ }^{28,29}$

\section{Material and methods}

A literature search for studies investigating different forms of BMS management was performed in PubMed, European Union Drug Regulating Authorities Clinical Trials Database (EudraCT), ClinicalTrials.gov, and Cochrane Central Register of Controlled Trials (CENTRAL), using the Population/Interest/Context (PICO) framework and the following search terms: "burning mouth syndrome", "BMS", "alpha-lipoic acid" AND "burning mouth syndrome", and "clonazepam" AND "burning mouth syndrome. ${ }^{30}$ No restrictions on the study size, year or duration were set. Titles were screened for relevance and duplicates were removed, while abstracts were screened according to the Preferred Reporting Items for Systematic Reviews and Meta-Analyses (PRISMA) recommendations. ${ }^{31}$ Trials that investigated the efficacy of different management approaches for BMS were included (Tables 1,2). The study populations included adult patients undergoing pharmacological or non-pharmacological treatment compared to placebos/controls for BMS management, with randomized controlled trials (RCTs) and case studies screened for relevancy.

\section{Outcome measures}

The primary efficacy outcome was the improvement in the VAS and Oral Health Impact Profile (OHIP) scores. Pharmacological management included alpha-lipoid acid (ALA), clonazepam, capsaicin, amisulpride, fluoxetine, trazodone, milnacipran, St. John's wort (Hypericum perforatum extract), melatonin, bupivacaine, benzydamine, and lidocaine lingual nerve injection (Table 1).

\section{Results}

\section{Pharmacological management of burning mouth syndrome}

As BMS appears to be associated with psychiatric comorbidities, a number of psychotropic drugs are used in its management, including antidepressants and clonazepam (Table 1$)^{2}$; psychotherapy has also been used (Table 2). 


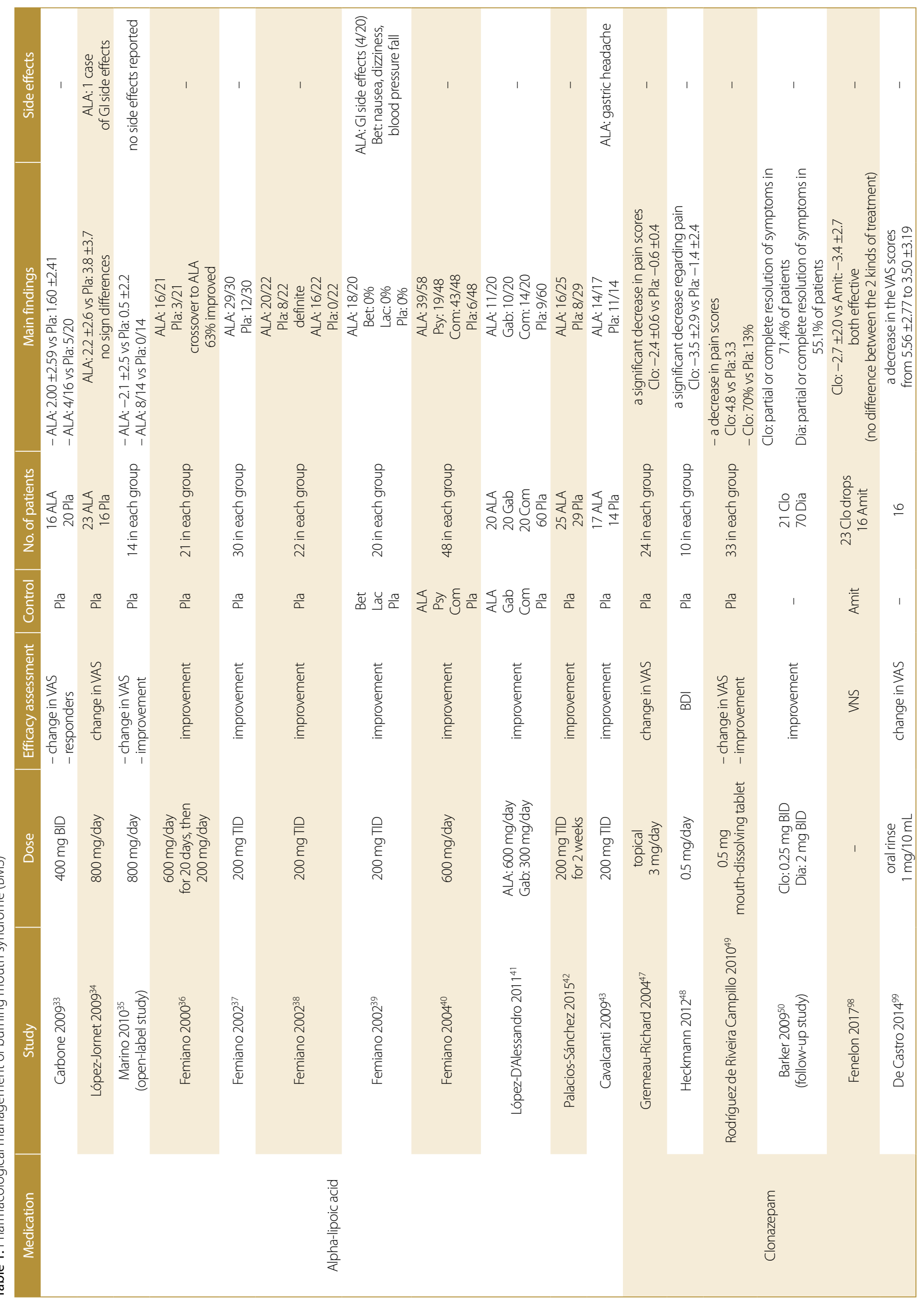




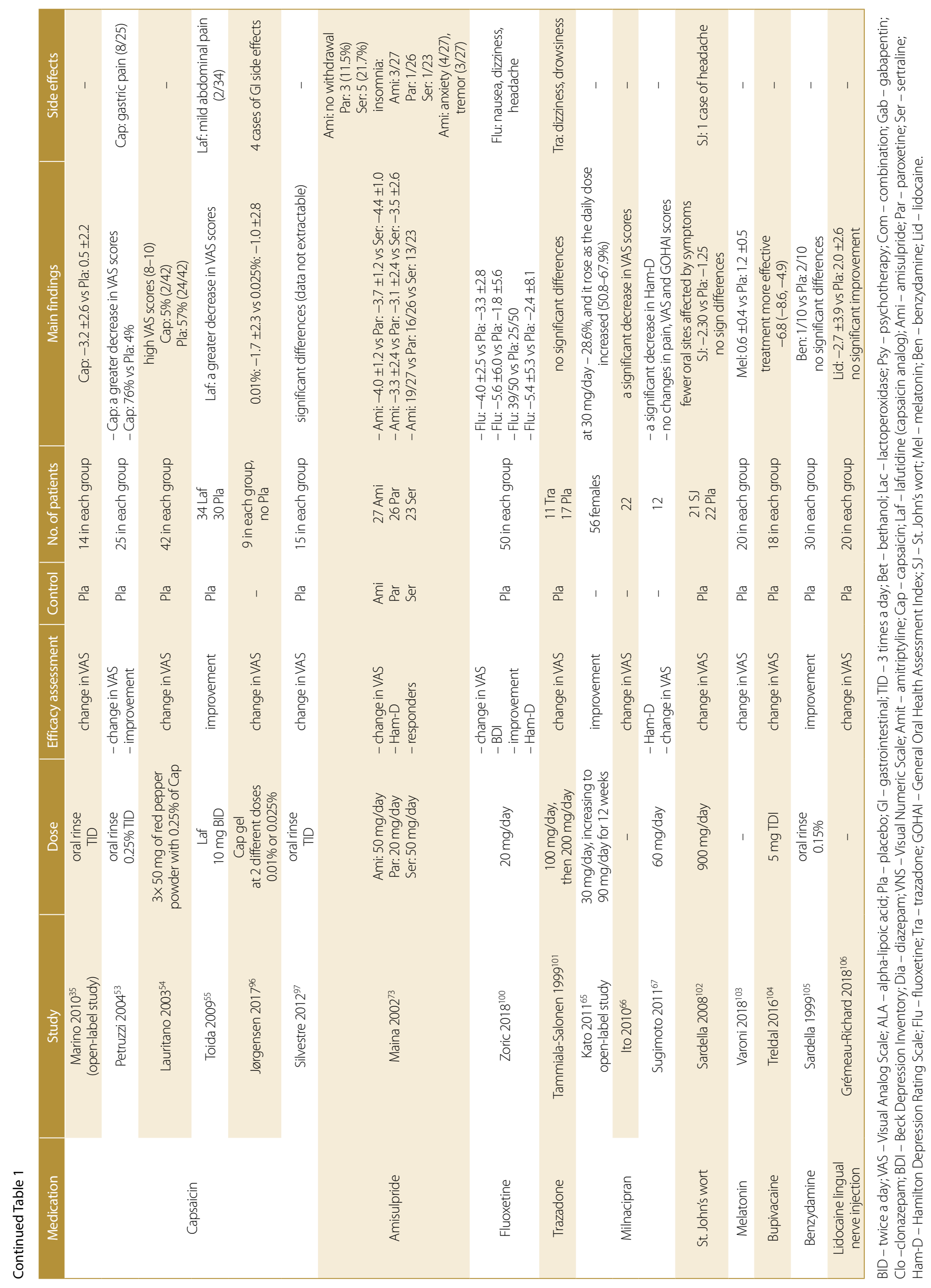




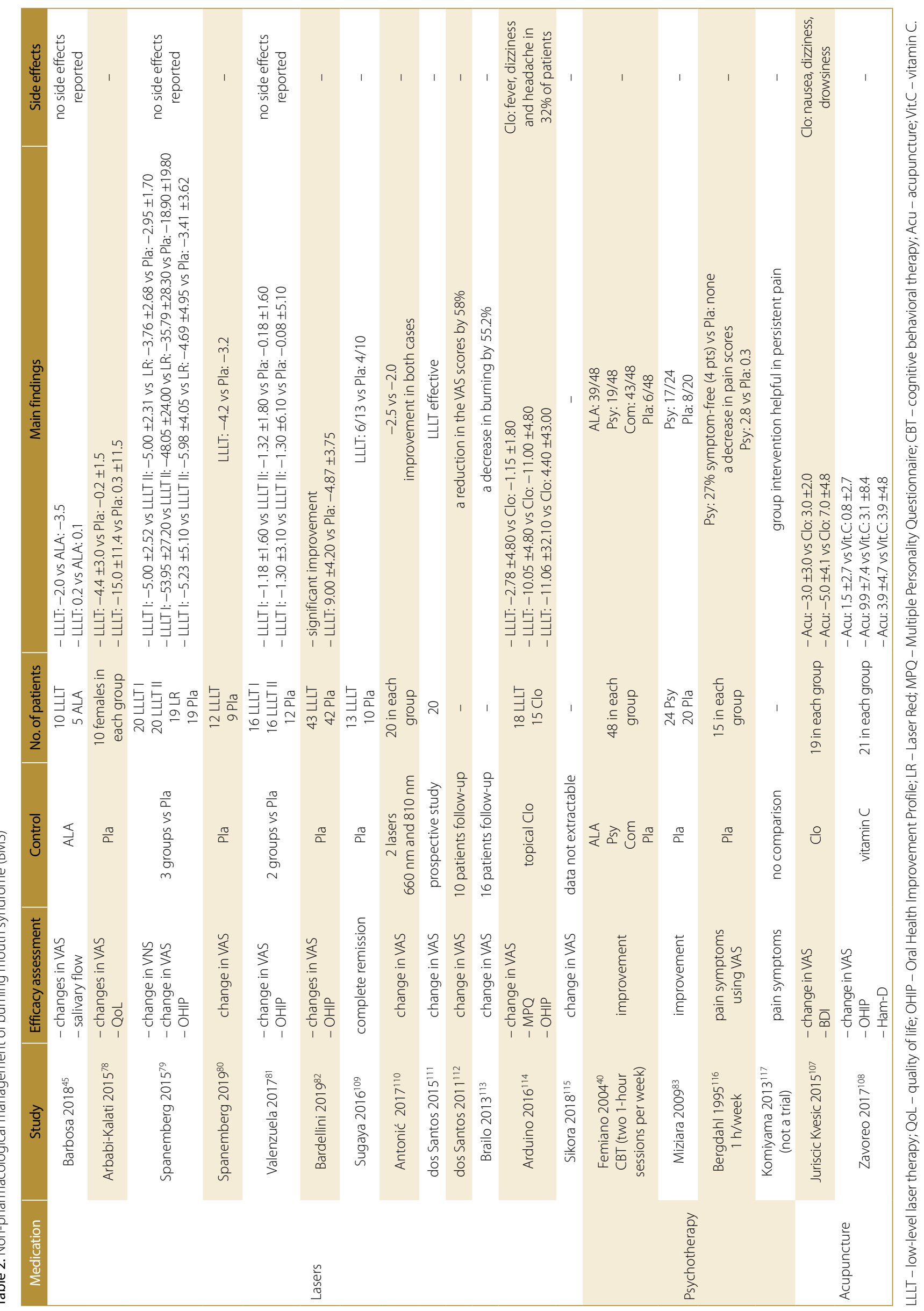




\section{Alpha-lipoic acid}

Alpha-lipoic acid is a free-radical scavenger, and its metabolite - dihydrolipoic acid - has antioxidant properties and can regenerate endogenous antioxidants (vitamin $\mathrm{E}$, vitamin $\mathrm{C}$ and glutathione). ${ }^{32}$ Alpha-lipoic acid is considered an effective medication for BMS management, as highlighted by the evidence obtained from trials measuring its efficacy by means of various methods, ${ }^{33-44}$ with some heterogeneity among the studies (Table 1). An interesting comparison with low-level laser therapy (LLLT) showed that both LLLT and ALA were efficient in treating BMS. ${ }^{45}$

\section{Benzodiazepines}

Benzodiazepines are hypnotics/sedatives that potentiate the action of the inhibitory neurotransmitter gamma aminobutyric acid (GABA). ${ }^{46}$ We found 3 trials that compared the efficacy of clonazepam against a placebo using the VAS scores. ${ }^{47-49}$ The overall results proved the effectiveness of clonazepam, as highlighted by a significant reduction in the VAS scores. Systemic clonazepam presented the best efficacy, with more than $70 \%$ of patients showing the partial or complete resolution of their oral symptoms as compared to just over $55 \%$ of patients on diazepam. ${ }^{50}$ Topical clonazepam was also effective, and considered more cost-effective than amisulpride, paroxetine and sertraline, ${ }^{51}$ while prazepam showed some efficacy as well. ${ }^{52}$

\section{Capsaicin}

We found 4 studies that measured the efficacy of capsaicin. ${ }^{35,53-55}$ The overall results showed a positive effect and a possible beneficial role of capsaicin in BMS management.

\section{Antidepressants}

Selective serotonin reuptake inhibitors (SSRIs) have low side-effect profiles and are particularly efficient in psychogenic BMS management. ${ }^{56}$ At low doses, they inhibit serotonin reuptake, and at high doses, they may inhibit noradrenaline reuptake as well. ${ }^{46}$ There have not been many trials pitting SSRIs against a placebo or control medication (Table 1), and most of the available evidence comes from case studies. Sertraline, a widely used antidepressant, resulted in a reduction in the severity of stomatodynia. ${ }^{57}$ Paroxetine proved to be efficacious, with complete pain remission in more than $70 \%$ of patients. ${ }^{58}$ In 1 study, painful burning sensations were elicited with fluoxetine treatment, and citalopram used as an alternative led to the remission of BMS associated with depression. ${ }^{59}$ On the other hand, clomipramine reduced pain in BMS patients at a level similar to a placebo. ${ }^{60}$
Venlafaxine and duloxetine are serotonin-norepinephrine reuptake inhibitors (SNRIs). Venlafaxine with clonazepam were successful in patients unresponsive to anticonvulsants and antidepressants. ${ }^{11}$ Duloxetine was observed to significantly relieve pain in case reports, and led to symptom remission and improvement in the quality of life (QoL). ${ }^{61,62}$ Moclobemide is a reversible inhibitor of monoamine oxidase, and it reduced anxiety, depression and the VAS scores among BMS patients. ${ }^{63}$

Milnacipran blocks serotonin and norepinephrine reuptake. It has a simple pharmacokinetics profile and no inhibitory effects on cytochrome P450 enzymes, so it is recommended for patients with multiple treatment regimens. ${ }^{64}$ Low-dose milnacipran ( $30 \mathrm{mg}$ daily) had a poor response; the cumulative improvement rate increased to $68 \%$ when the daily dose was increased from $60 \mathrm{mg}$ to $90 \mathrm{mg} .{ }^{65}$ Milnacipran reportedly brought about significant reductions in the VAS scores, ${ }^{66}$ reduced depression and improved patients' QoL, ${ }^{67}$ but there have not been enough trials comparing milnacipran to a placebo or control medication (Table 1). Most of the available evidence of the efficacy of milnacipran comes from case studies, such as that of a 71-year-old with no satisfactory response to psychotropic drugs who recovered from BMS when sertraline was replaced with milnacipran. ${ }^{68}$

\section{Antipsychotics and anti-Parkinson medications}

For antipsychotics and anti-Parkinson drugs, there is not enough data comparing a placebo or control medication with these medications, and most of the evidence comes from case studies. Olanzapine, an antipsychotic, caused rapid significant improvement in treating BMS, ${ }^{69}$ even in patients unresponsive to milnacipran or paroxetine. ${ }^{70}$ Aripiprazole ameliorated chronic burning pain, ${ }^{71}$ while levosulpiride and amisulpride alleviated oral symptoms. $^{72,73}$ A case of refractory BMS showed complete relief after treatment with pramipexol. ${ }^{74}$ The BMS symptoms also responded to levodopa. ${ }^{7}$

\section{Anticonvulsants}

Pregabalin was successful in patients unresponsive to milnacipran or duloxetine. ${ }^{75}$ Gabapentin - a structural analog of GABA - reduced oral burning, while nortriptyline and sertraline were contraindicated. ${ }^{76}$ However, another study failed to confirm the efficacy of gabapentin in BMS. ${ }^{77}$

\section{Non-pharmacological management of burning mouth syndrome}

The most common non-pharmacological interventions are LLLT, psychotherapy and acupuncture.

We found 4 trials measuring the efficacy of LLLT using the VAS scores ${ }^{78-81}$ and 3 trials measuring its efficacy 
using OHIP (Table 2). ${ }^{79,81,82}$ The overall results showed positive effects on both VAS and OHIP. Interestingly, a comparison with ALA showed similar efficacy. ${ }^{45}$

Two trials measured the efficacy of psychotherapy in alleviating the BMS symptoms, ${ }^{40,83}$ but there have not been enough trials studying the efficacy of acupuncture as compared to a placebo or control medication (Table 2).

\section{Discussion}

Both the diagnosis and management of BMS are unclear. ${ }^{3}$ Burning mouth syndrome is known as a chronic condition with pain intensity increasing from morning to evening. ${ }^{84}$ The tongue is the most commonly affected site, followed by the lower lip and the hard palate. ${ }^{84}$ Burning mouth syndrome could be due to immunological or endocrine etiology, and some recent evidence suggests neurophysiological mechanisms, such as a peripheral small-fiber neuropathy or central neuropathic disturbances. ${ }^{9}$ Risk factors include metabolic disorders, vitamin deficiencies ${ }^{85}$ or medications, i.a., angiotensin-converting enzyme inhibitors and anticoagulants. ${ }^{86}$

The prevalence of BMS can be especially high in psychiatric patients, ${ }^{87}$ and it is associated with comorbidities such as depression and anxiety. ${ }^{88}$ Assessment and outcome measurements include the VAS scores, QoL ratings, taste, and the salivary flow. ${ }^{2}$

Multiple kinds of pharmacological treatment have been tried, including ALA, milnacipran, benzodiazepines, antidepressants, anticonvulsants, and atypical antipsychotics (Table 3). ${ }^{87}$ Topical clonazepam is used for peripheral BMS, while central BMS is managed with antidepressants, anti-seizure medications or antipsychotics, ${ }^{89}$ but the evidence of their efficacy is weak, as the power of the studies and the numbers of patients have been relatively low, and most studies have had short follow-up periods with high variability.

Burning mouth syndrome could have a neuropathic origin, and experts recommend neuropathic pain agents, such as amitriptyline, gabapentin, benzodiazepines, antipsychotics, ${ }^{90}$ or mood-altering interventions. ${ }^{91}$ Our study highlights that ALA, clonazepam and capsaicin may bring promising results (Table 4); however, more studies are needed, with longer follow-up periods and larger numbers of patients. Alpha-lipoic acid and clonazepam have shown modest evidence of decreasing BMS. ${ }^{92}$ The overall quality of the evidence of effectiveness remains low for all pharmacological and non-pharmacological interventions.

Our review has some limitations. There was high heterogeneity among the studies and there were few clinical trials for most of the management options. Different methods were used to present the findings, while some trials had missing data (Tables 1,2).

Combination treatment has shown promising results. Alpha-lipoic acid with gabapentin, ${ }^{41}$ sertraline with cognitive
Table 3. Summary of the available evidence for the pharmacological management of burning mouth syndrome (BMS)

\begin{tabular}{|c|c|}
\hline Medication & As per current clinical research \\
\hline Alpha-lipoic acid & $\begin{array}{l}\text { Positive outcome demonstrated with improvement } \\
\text { in the VAS scores in several trials; however, RCT } \\
\text { failed to support its role - further research needed. }\end{array}$ \\
\hline Milnacipran & $\begin{array}{l}\text { Weak scientific evidence that milnacipran (60-90 mg) } \\
\text { could result in a significant reduction in the VAS scores. }\end{array}$ \\
\hline Benzodiazepines & $\begin{array}{l}\text { Research suggests the efficacy of systemic } \\
\text { clonazepam or its application in the form of oral } \\
\text { rinse - large clinical trials still needed to confirm. }\end{array}$ \\
\hline Antidepressants & $\begin{array}{l}\text { Scientific evidence mostly from case studies. Sertraline } \\
\text { and paroxetine were efficacious with a reduction in } \\
\text { the severity of BMS. In case reports, venlafaxine and } \\
\text { duloxetine significantly relieved pain. Moclobemide } \\
\text { reduced anxiety, depression and the VAS scores. }\end{array}$ \\
\hline $\begin{array}{l}\text { Antipsychotics and } \\
\text { anti-parkinsonism } \\
\text { medications }\end{array}$ & $\begin{array}{l}\text { In case studies, olanzapine and aripiprazole caused } \\
\text { improvement - RCTs lacking. Weak scientific evidence } \\
\text { for the efficacy of amisulpride. Case studies highlighted } \\
\text { pramipexol and levodopa as promising medications. }\end{array}$ \\
\hline Anticonvulsants & $\begin{array}{l}\text { Case studies highlighted gabapentin and } \\
\text { pregabalin as promising medications despite the } \\
\text { presence of some contradictory results. One clinical } \\
\text { trial highlighted the possible efficacy of gabapentin, } \\
\text { especially in combination with ALA. }\end{array}$ \\
\hline
\end{tabular}

$\mathrm{RCT}$ - randomized clinical trial.

Table 4. Characteristics of the main pharmacological therapies for the management of burning mouth syndrome (BMS)

\begin{tabular}{|c|c|c|c|}
\hline Medication & Dosage & Duration & Possible side effects \\
\hline $\begin{array}{l}\text { Alpha-lipoic } \\
\text { acid }\end{array}$ & $\begin{array}{c}\text { 600-800 mg/day } \\
\text { in 2-3 divided } \\
\text { doses }\end{array}$ & $2-4$ weeks & $\begin{array}{c}\text { rare minor abdominal } \\
\text { pain, headache, and rarely } \\
\text { hypersensitivity }\end{array}$ \\
\hline \multirow{2}{*}{ Clonazepam } & $\begin{array}{l}\text { oral tablets } \\
0.5 \mathrm{mg} / \text { day }\end{array}$ & 2-4 weeks & \multirow{2}{*}{$\begin{array}{c}\text { fatigue, muscle weakness, } \\
\text { nausea, somnolence, rash, } \\
\text { headache, and impaired } \\
\text { concentration }\end{array}$} \\
\hline & $\begin{array}{l}\text { oral rinse } \\
1 \mathrm{mg} / 10 \mathrm{~mL}\end{array}$ & 2-4 weeks & \\
\hline \multirow{2}{*}{ Capsaicin } & $\begin{array}{l}\text { systemic } \\
0.25 \%\end{array}$ & 2-4 weeks & \multirow{2}{*}{$\begin{array}{l}\text { mild abdominal pain, and } \\
\text { rarely hypersensitivity }\end{array}$} \\
\hline & $\begin{array}{l}\text { oral rinse } \\
0.025 \% \text { TID }\end{array}$ & 2-4 weeks & \\
\hline Milnacipran & 30-90 mg/day & 2-4 weeks & $\begin{array}{c}\text { dizziness, hot flash, nausea, } \\
\text { insomnia, palpitations, rash, } \\
\text { headache, and xerostomia }\end{array}$ \\
\hline
\end{tabular}

behavioral therapy, ${ }^{93}$ and tranylcypromine with low-dose anxiolytics and psychotherapy have been effective in refractory BMS.94 Non-pharmacological interventions, such as LLLT or psychotherapy, have shown some efficacy. However, large-scale clinical trials with long follow-up periods are still needed to confirm these findings. ${ }^{89}$ Treatment should be tailored with careful history-taking and consultations among a variety of health professionals, including psychiatrists, dentists, pain specialists, and neurologists with a special interest in headaches, to avoid potential delays in diagnosis. ${ }^{85,95}$ A clinical diagnosis should include the assessment of the nutritional status and comprehensive dental evaluation. ${ }^{96}$ The management of BMS should include managing anxiety, depression and pain disorders, ruling out treatable conditions, 
and discussing different management options with the patient. ${ }^{97}$ Non-pharmacological interventions could be tried first, if clinically appropriate, and compatible with the patient's preferences and the severity of the symptoms. If pharmacotherapy is appropriate, ALA or capsaicin could be first choice because of favorable side-effect profiles, while clonazepam or milnacipran could be second-line medications for BMS management due to their side effects - particularly cognitive ones - and an increased risk of dependence associated with benzodiazepines.

\section{ORCID iDs}

Ayman Antoun Reyad (D) https://orcid.org/0000-0003-0657-4606 Raafat Mishriky (D) https://orcid.org/0000-0003-3007-0264 Eriny Girgis (D) https://orcid.org/0000-0002-0786-5969

\section{References}

1. Grushka M, Ching V. Preliminary exploration of burning mouth and burning feet: Is there a common etiology? Pain Res Manag. 2005;10(3):166-167.

2. Kisely S, Forbes M, Sawyer E, Black E, Lalloo R. A systematic review of randomized trials for the treatment of burning mouth syndrome. J Psychosom Res. 2016;86:39-46.

3. Sinding C, Gransjøen AM, Schlumberger G, Grushka M, Frasnelli J, Singh PB. Grey matter changes of the pain matrix in patients with burning mouth syndrome. Eur J Neurosci. 2016;43(8):997-1005.

4. Almoznino G, Benoliel R, Sharav Y, Haviv Y. Sleep disorders and chronic craniofacial pain: Characteristics and management possibilities. Sleep Med Rev. 2017;33:39-50.

5. Headache Classification Committee of the International Headache Society (IHS). The international classification of headache disorders, $3^{\text {rd }}$ edition. Cephalalgia. 2018;38(1):1-211.

6. Asplund R. Sleep, nocturia and the burning mouth syndrome (BMS) in the elderly. Sleep Hypnos. 2006;8(1):6-11.

7. Prakash $S$, Ahuja $S$, Rathod C. Dopa responsive burning mouth syndrome: Restless mouth syndrome or oral variant of restless legs syndrome? J Neurol Sci. 2012;320(1-2):156-160.

8. Corsalini M, Di Venere D, Pettini F, Lauritano D, Petruzzi M. Temporomandibular disorders in burning mouth syndrome patients: An observational study. Int J Med Sci. 2013;10(12):1784-1789.

9. Jääskeläinen SK. Pathophysiology of primary burning mouth syndrome. Clin Neurophysiol. 2012;123(1):71-77.

10. Kim Y, Kim HI, Kho HS. Characteristics of men and premenopausal women with burning mouth symptoms: A case-control study. Headache. 2014;54(5):888-898.

11. Mitsikostas DD, Ljubisavljevic S, Deligianni Cl. Refractory burning mouth syndrome: Clinical and paraclinical evaluation, comorbidities, treatment and outcome. J Headache Pain. 2017;18(1):40-45.

12. Dangore-Khasbage S, Khairkar PH, Degwekar SS, et al. Prevalence of oral mucosal disorders in institutionalized and non-institutionalized psychiatric patients: A study from AVBR hospital in Central India. J Oral Sci. 2012;54(1):85-91.

13. Kossioni AE, Kossionis GE, Polychronopoulou A. Self-reported oral complaints in older mentally ill patients. Geriatr Gerontol Int. 2013;13(2):358-364.

14. Pajukoski H, Meurman JH, Halonen P, Sulkava R. Prevalence of subjective dry mouth and burning mouth in hospitalized elderly patients and outpatients in relation to saliva, medication, and systemic diseases. Oral Surg Oral Med Oral Pathol Oral Radiol Endod. 2001;92(6):641-649.

15. Maltsman-Tseikhin A, Moricca P, Niv D. Burning mouth syndrome: Will better understanding yield better management? Pain Pract. 2007;7(2):151-162.

16. Heckmann SM, Heckmann JG, Hilz MJ, et al. Oral mucosal blood flow in patients with burning mouth syndrome. Pain. 2001;90(3):281-286.

17. Eliav E. Altered structure and function in hippocampus and medial frontal cortex in patients with burning mouth syndrome. Pain. 2014;155(8):1424-1425.
18. Penza $P$, Majorana A, Lombardi $R$, et al. "Burning tongue" and "burning tip": The diagnostic challenge of the burning mouth syndrome. Clin J Pain. 2010;26(6):528-532.

19. Albuquerque RJ, de Leeuw R, Carlson CR, Okeson JP, Miller CS, Andersen $\mathrm{AH}$. Cerebral activation during thermal stimulation of patients who have burning mouth disorder: An fMRI study. Pain. 2006;122(3):223-234.

20. Forssell H, Jääskeläinen S, Tenovuo O, Hinkka S. Sensory dysfunction in burning mouth syndrome. Pain. 2002;99(1-2):41-47.

21. Koike K, Shinozaki T, Hara K, et al. Immune and endocrine function in patients with burning mouth syndrome. Clin J Pain. 2014;30(2):168-173.

22. Guimarães ALS, de Sá AR, Victoria JMN, de Fátima Correia-Silva J, Gomez MV, Gomez RS. Interleukin-1beta and serotonin transporter gene polymorphisms in burning mouth syndrome patients. J Pain. 2006;7(9):654-658.

23. Tokura $T$, Kimura $H$, Ito $M$, et al. Temperament and character profiles of patients with burning mouth syndrome. J Psychosom Res. 2015;78(5):495-498.

24. de Souza FTA, Teixeira AL, Amaral TMP, et al. Psychiatric disorders in burning mouth syndrome. J Psychosom Res. 2012;72(2):142-146.

25. Takenoshita M, Sato T, Kato $Y$, et al. Psychiatric diagnoses in patients with burning mouth syndrome and atypical odontalgia referred from psychiatric to dental facilities. Neuropsychiatr Dis Treat. 2010;6:699-705.

26. Matthews RW, Paterson AJ, Scully C. Burning mouth syndrome: Patients' views. Med Sci Res. 1992;20(22):837-839.

27. Schiavone V, Adamo D, Ventrella G, et al. Anxiety, depression, and pain in burning mouth syndrome: First chicken or egg? Headache. 2012;52(6):1019-1025.

28. Coon EA, Laughlin RS. Burning mouth syndrome in Parkinson's disease: Dopamine as cure or cause? J Headache Pain. 2012;13(3):255-257.

29. Hagelberg N, Forssell H, Rinne JO, et al. Striatal dopamine D1 and D2 receptors in burning mouth syndrome. Pain. 2003;101(1-2):149-154.

30. Cochrane Training. Cochrane Information Specialists' Handbook. https://training.cochrane.org/resource/cochrane-information-specialists-handbook. Updated 2020. Accessed on April 21, 2020.

31. Moher D, Liberati A, Tetzlaff J, Altman DG; PRISMA Group. Preferred reporting items for systematic reviews and meta-analyses: The PRISMA statement. J Clin Epidemiol. 2009;62(10):1006-1012.

32. Biewenga GP, Haenen GR, Bast A. The pharmacology of the antioxidant lipoic acid. Gen Pharmacol. 1997;29(3):315-331.

33. Carbone $M$, Pentenero M, Carrozzo M, Ippolito A, Gandolfo S. Lack of efficacy of alpha-lipoic acid in burning mouth syndrome: A double-blind, randomized, placebo-controlled study. Eur J Pain. 2009;13(5):492-496.

34. López-Jornet $P$, Camacho-Alonso F, Leon-Espinosa S. Efficacy of alpha lipoic acid in burning mouth syndrome: A randomized, placebo-treatment study. J Oral Rehabil. 2009;36(1):52-57.

35. Marino R, Torretta S, Capaccio P, Pignataro L, Spadari F. Different therapeutic strategies for burning mouth syndrome: Preliminary data. J Oral Pathol Med. 2010;39(8):611-616.

36. Femiano F, Gombos F, Scully C, Busciolano M, De Luca P. Burning mouth syndrome (BMS): Controlled open trial of the efficacy of alpha-lipoic acid (thioctic acid) on symptomatology. Oral Dis. 2000;6(5):274-277.

37. Femiano F, Scully C. Burning mouth syndrome (BMS): Double blind controlled study of alpha-lipoic acid (thioctic acid) therapy. J Oral Pathol Med. 2002;31(5):267-269.

38. Femiano F, Scully C, Gombos F. Idiopathic dysgeusia; an open trial of alpha lipoic acid (ALA) therapy. Int J Oral Maxillofac Surg. 2002;31(6):625-628.

39. Femiano F. Burning mouth syndrome (BMS): An open trial of comparative efficacy of alpha-lipoic acid (thioctic acid) with other therapies. Minerva Stomatol. 2002;51(9):405-409.

40. Femiano F, Gombos F, Scully C. Burning mouth syndrome: Open trial of psychotherapy alone, medication with alpha-lipoic acid (thioctic acid), and combination therapy. Med Oral. 2004;9(1):8-13.

41. López-D'Alessandro E, Escovich L. Combination of alpha lipoic acid and gabapentin, its efficacy in the treatment of burning mouth syndrome: A randomized, double-blind, placebo controlled trial. Med Oral Patol Oral Cir Bucal. 2011;16(5):e635-e640. 
42. Palacios-Sánchez B, Moreno-López LA, Cerero-Lapiedra R, LlamasMartínez S, Esparza-Gómez G. Alpha lipoic acid efficacy in burning mouth syndrome. A controlled clinical trial. Med Oral Patol Oral Cir Bucal. 2015;20(4):e435-e440.

43. Cavalcanti DR, da Silveira FRX. Alpha lipoic acid in burning mouth syndrome - a randomized double-blind placebo-controlled trial. J Oral Pathol Med. 2009;38(3):254-261.

44. Femiano F, Gombos F, Scully C. Burning mouth syndrome: The efficacy of lipoic acid on subgroups. J Eur Acad Dermatol Venereol. 2004;18(6):676-678

45. Barbosa NG, Goes Gonzaga AK, de Sena Fernandes LL, et al. Evaluation of laser therapy and alpha-lipoic acid for the treatment of burning mouth syndrome: A randomized clinical trial. Lasers Med Sci. 2018:33(6):1255-1262.

46. Golan DE, Armstrong EJ, Armstrong AW. Principles of Pharmacology: The Pathophysiologic Basis of Drug Therapy. $4^{\text {th }}$ ed. Philadelphia, PA: Wolters Kluvwer; 2017.

47. Gremeau-Richard C, Woda A, Navez ML, et al. Topical clonazepam in stomatodynia: A randomised placebo-controlled study. Pain. 2004;108(1-2):51-57.

48. Heckmann SM, Kirchner E, Grushka M, Wichmann MG, Hummel T. A double-blind study on clonazepam in patients with burning mouth syndrome. Laryngoscope. 2012;122(4):813-816.

49. Rodríguez de Rivera Campillo E, López-López J, Chimenos-Küstner E. Response to topical clonazepam in patients with burning mouth syndrome: A clinical study. Bull Group Int Rech Sci Stomatol Odontol. 2010;49(1):19-29.

50. Barker KE, Batstone MD, Savage NW. Comparison of treatment modalities in burning mouth syndrome. Aust Dent J. 2009;54(4):300-305; quiz 396.

51. Hens MJ, Alonso-Ferreira V, Villaverde-Hueso A, Abaitua I, Posada de la Paz M. Cost-effectiveness analysis of burning mouth syndrome therapy. Community Dent Oral Epidemiol. 2012;40(2):185-192.

52. Guarneri F, Guarneri C, Marini H. Contribution of neuroinflammation in burning mouth syndrome: Indications from benzodiazepine use. Dermatol Ther. 2008;21(Suppl 2):S21-S24.

53. Petruzzi M, Lauritano D, De Benedittis M, Baldoni M, Serpico R. Systemic capsaicin for burning mouth syndrome: Short-term results of a pilot study. J Oral Pathol Med. 2004;33(2):111-114.

54. Lauritano D, Petruzzi M, Baldoni M. Preliminary protocol for systemic administration of capsaicin for the treatment of the burning mouth syndrome [in Italian]. Minerva Stomatol. 2003;52(6):273-278.

55. Toida $\mathrm{M}, \mathrm{Kato} \mathrm{K}, \mathrm{Makita} \mathrm{H}$, et al. Palliative effect of lafutidine on oral burning sensation. J Oral Pathol Med. 2009;38(3):262-268.

56. Fleuret C, Le Toux G, Morvan J, et al. Use of selective serotonin reuptake inhibitors in the treatment of burning mouth syndrome. Dermatology. 2014;228(2):172-176.

57. Gruden SJP, Vidas M, Gruden V. Stomatodynia - an indication for antidepressant therapy. Soc Psihijatrija. 2004;32(2):90-93.

58. Yamazaki Y, Hata H, Kitamori S, Onodera M, Kitagawa Y. An openlabel, noncomparative, dose escalation pilot study of the effect of paroxetine in treatment of burning mouth syndrome. Oral Surg Oral Med Oral Pathol Oral Radiol Endod. 2009;107(1):e6-e11.

59. Ginsberg DL. Eating disorders over the lifecycle: Diagnosis and treatment. Primary Psych. 2003;10(6):15.

60. Loldrup D, Langemark M, Hansen HJ, Olesen J, Bech P. Clomipramine and mianserin in chronic idiopathic pain syndrome. A placebo controlled study. Psychopharmacology (Berl). 1989;99(1):1-7.

61. Mignogna MD, Adamo D, Schiavone V, Ravel MG, Fortuna G. Burning mouth syndrome responsive to duloxetine: $\mathrm{A}$ case report. Pain Med. 2011;12(3):466-469.

62. Kim YD, Lee JH, Shim JH. Duloxetine in the treatment of burning mouth syndrome refractory to conventional treatment: A case report. J Int Med Res. 2014;42(3):879-883.

63. Pekiner FN, Gumru B, Ozbayrak S. Efficacy of moclobemide in burning mouth syndrome: A nonrandomized, open-label study. J Orofac Pain. 2008;22(2):146-152.

64. Pae CU. Milnacipran for chronic pain in the orofacial region. Clin Neuropharmacol. 2010;33(5):270.

65. Kato Y, Sato T, Katagiri A, et al. Milnacipran dose-effect study in patients with burning mouth syndrome. Clin Neuropharmacol. 2011;34(4):166-169.
66. Ito M, Kimura H, Yoshida K, Kimura Y, Ozaki N, Kurita K. Effectiveness of milnacipran for the treatment of chronic pain in the orofacial region. Clin Neuropharmacol. 2010;33(2):79-83.

67. Sugimoto $K$. The dubious effect of milnacipran for the treatment of burning mouth syndrome. Clin Neuropharmacol. 2011;34(4):170-173.

68. Ukai K, Kimura $H$, Arao $M$, et al. Effectiveness of low-dose milnacipran for a patient suffering from pain disorder with delusional disorder (somatic type) in the orofacial region. Psychogeriatrics. 2013;13(2):99-102.

69. Ferensztajn E, Łojko D, Rybakowski J. Burning mouth syndrome: Pathogenic and therapeutic concepts. Psychiatr Pol. 2013;47(6):973-988.

70. Ueda N, Kodama $\mathrm{Y}$, Hori $\mathrm{H}$, et al. Two cases of burning mouth syndrome treated with olanzapine. Psychiatry Clin Neurosci. 2008;62(3):359-361.

71. Umezaki Y, Takenoshita M, Toyofuku A. Low-dose aripiprazole for refractory burning mouth syndrome. Neuropsychiatr Dis Treat. 2016;12:1229-1231.

72. Demarosi F, Tarozzi M, Lodi G, Canegallo L, Rimondini L, Sardella A. The effect of levosulpiride in burning mouth syndrome. Minerva Stomatol. 2007;56(1-2):21-26

73. Maina G, Vitalucci A, Gandolfo S, Bogetto F. Comparative efficacy of SSRIs and amisulpride in burning mouth syndrome: A singleblind study. J Clin Psychiatry. 2002;63(1):38-43.

74. Stuginski-Barbosa J, Rodrigues GGR, Bigal ME, Speciali JG. Burning mouth syndrome responsive to pramipexol. J Headache Pain. 2008;9(1):43-45.

75. Ito $M$, Tokura $T$, Yoshida $K$, et al. Five patients with burning mouth syndrome in whom an antidepressant (serotonin-noradrenaline reuptake inhibitor) was not effective, but pregabalin markedly relieved pain. Clin Neuropharmacol. 2015;38(4):158-161.

76. White TL, Kent PF, Kurtz DB, Emko P. Effectiveness of gabapentin for treatment of burning mouth syndrome. Arch Otolaryngol Head Neck Surg. 2004;130(6):786-788.

77. Heckmann SM, Heckmann JG, Ungethüm A, Hujoel $P$, Hummel T. Gabapentin has little or no effect in the treatment of burning mouth syndrome - results of an open-label pilot study. Eur J Neurol. 2006;13(7):e6-e7.

78. Arbabi-Kalati F, Bakhshani NM, Rasti M. Evaluation of the efficacy of low-level laser in improving the symptoms of burning mouth syndrome. J Clin Exp Dent. 2015;7(4):e524-e527.

79. Spanemberg JC, López-López J, de Figueiredo MAZ, Cherubini K, Salum FG. Efficacy of low-level laser therapy for the treatment of burning mouth syndrome: A randomized, controlled trial. J Biomed Opt. 2015;20(9):098001.

80. Spanemberg JC, Segura-Egea JJ, Rodríguez-de Rivera-Campillo E, Jané-Salas E, Salum FG, López-López J. Low-level laser therapy in patients with burning mouth syndrome: A double-blind, randomized, controlled clinical trial. J Clin Exp Dent. 2019;11(2):e162-e169.

81. Valenzuela S, López-Jornet P. Effects of low-level laser therapy on burning mouth syndrome. J Oral Rehabil. 2017:44(2):125-132.

82. Bardellini E, Amadori F, Conti G, Majorana A. Efficacy of the photobiomodulation therapy in the treatment of the burning mouth syndrome. Med Oral Patol Oral Cir Bucal. 2019;24(6):e787-e791.

83. Miziara ID, Filho BCA, Oliveira R, dos Santos RMR. Group psychotherapy: An additional approach to burning mouth syndrome. J Psychosom Res. 2009;67(5):443-448.

84. Forssell $\mathrm{H}$, Teerijoki-Oksa T, Kotiranta U, et al. Pain and pain behaviour in burning mouth syndrome: A pain diary study. J Orofac Pain. 2012;26(2):117-125.

85. Lewis AK, Prime SS, Cohen SN. An overview of burning mouth syndrome for the dermatologist. Clin Exp Dermatol. 2016;41(2):119-123.

86. Raghavan SA, Puttaswamiah RN, Birur PN, Ramaswamy B, Sunny SP. Antidepressant-induced burning mouth syndrome: A unique case. Korean J Pain. 2014;27(3):294-296.

87. Buchanan JA, Zakrzewska JM. Burning mouth syndrome. BMJ Clin Evid. 2010;2010:1301.

88. Zakrzewska JM. Multi-dimensionality of chronic pain of the oral cavity and face. J Headache Pain. 2013;14(1):37.

89. Silvestre FJ, Silvestre-Rangil J, López-Jornet P. Burning mouth syndrome: A review and update. Rev Neurol. 2015:60(10):457-463.

90. Spanemberg JC, Cherubini K, de Figueiredo MAZ, Yurgel LS, Salum FG. Aetiology and therapeutics of burning mouth syndrome: An update. Gerodontology. 2012;29(2):84-89. 
91. Gorsky M, Silverman S Jr., Chinn H. Clinical characteristics and management outcome in the burning mouth syndrome. An open study of 130 patients. Oral Surg Oral Med Oral Pathol. 1991;72(2):192-195.

92. Liu YF, Kim Y, Yoo T, Han P, Inman JC. Burning mouth syndrome: A systematic review of treatments. Oral Dis. 2018;24(3):325-334.

93. Eryılmaz A, Ayrancı Ü. Burning mouth syndrome: A case presentation [in Turkish]. Anadolu Psikiyatri Derg. 2002;3(3):169-173.

94. Grinspan D, Fernández Blanco G, Allevato MA, Stengel FM. Burning mouth syndrome. Int J Dermatol. 1995;34(7):483-487.

95. Klasser GD, Epstein JB, Villines D, Utsman R. Burning mouth syndrome: A challenge for dental practitioners and patients. Gen Dent. 2011;59(3):210-220;quiz 221-222.

96. Jørgensen MR, Pedersen AML. Analgesic effect of topical oral capsaicin gel in burning mouth syndrome. Acta Odontol Scand. 2017;75(2):130-136.

97. Silvestre FJ, Silvestre-Rangil J, Tamarit-Santafé C, Bautista D. Application of a capsaicin rinse in the treatment of burning mouth syndrome. Med Oral Patol Oral Cir Bucal. 2012;17(1):e1-e4.

98. Fenelon M, Quinque E, Arrive E, Catros S, Fricain JC. Pain-relieving effects of clonazepam and amitriptyline in burning mouth syndrome: A retrospective study. Int J Oral Maxillofac Surg. 2017;46(11):1505-1511.

99. de Castro LA, Ribeiro-Rotta RF. The effect of clonazepam mouthwash on the symptomatology of burning mouth syndrome: An open pilot study. Pain Med. 2014;15(12):2164-2165.

100. Zoric B, Jankovic L, Kuzmanovic Pficer J, Zidverc-Trajkovic J, Mijajlovic M, Stanimirovic D. The efficacy of fluoxetine in BMS - a cross-over study. Gerodontology. 2018;35(2):123-128.

101. Tammiala-Salonen T, Forssell $\mathrm{H}$. Trazodone in burning mouth pain: A placebo-controlled, double-blind study. J Orofac Pain. 1999;13(2):83-88.

102. Sardella A, Lodi G, Demarosi F, Tarozzi M, Canegallo L, Carrassi A. Hypericum perforatum extract in burning mouth syndrome: A randomized placebo-controlled study. J Oral Pathol Med. 2008;37(7):395-401.

103. Varoni EM, Lo Faro AF, Lodi G, Carrassi A, Iriti M, Sardella A. Melatonin treatment in patients with burning mouth syndrome: A triple-blind, placebo-controlled, crossover randomized clinical trial. J Oral Facial Pain Headache. 2018;32(2):178-188.

104. Treldal C, Jacobsen CB, Mogensen S, et al. Effect of a local anesthetic lozenge in relief of symptoms in burning mouth syndrome. Oral Dis. 2016;22(2):123-131.

105. Sardella A, Uglietti D, Demarosi F, Lodi G, Bez C, Carrassi A. Benzydamine hydrochloride oral rinses in management of burning mouth syndrome. A clinical trial. Oral Surg Oral Med Oral Pathol Oral Radiol Endod. 1999;88(6):683-686.

106. Grémeau-Richard C, Dubray C, Aublet-Cuvelier B, Ughetto S, Woda A. Effect of lingual nerve block on burning mouth syndrome (stomatodynia): A randomized crossover trial. Pain. 2010;149(1):27-32.

107. Jurisic Kvesic A, Zavoreo I, Basic Kes V, et al. The effectiveness of acupuncture versus clonazepam in patients with burning mouth syndrome. Acupunct Med. 2015;33(4):289-292.

108. Zavoreo I, Vučićević Boras V, Zadravec D, et al. The significance of brain transcranial sonography in burning mouth syndrome: A pilot study. Acta Stomatol Croat. 2017;51(1):48-59.

109. Sugaya NN, da Silva EFP, Kato IT, Prates R, de Barros Gallo C, Pellegrini VD. Low intensity laser therapy in patients with burning mouth syndrome: A randomized, placebo-controlled study. Braz Oral Res. 2016;30(1):e108.

110. Antonić R, Brumini M, Vidovic I, Muhvić Urek M, Glazar I, PezeljRibarić $S$. The effects of low level laser therapy on the management of chronic idiopathic orofacial pain: Trigeminal neuralgia, temporomandibular disorders and burning mouth syndrome. Medicina Flum. 2017;53(1):61-67.

111. dos Santos LdFC, de Andrade SC, Nogueira GEC, Leão JC, de Freitas PM. Phototherapy on the treatment of burning mouth syndrome: A prospective analysis of 20 cases. Photochem Photobiol. 2015;91(5):1231-1236.

112. dos Santos LdFC, Carvalho AdAT, Leão JC, da Cruz Perez DE, de Castro JFL. Effect of low-level laser therapy in the treatment of burning mouth syndrome: A case series. Photomed Laser Surg. 2011;29(12):793-796.
113. Brailo V, Bosnjak A, Vucicevic Boras V, Kvesic Jurisic A, Pelivan I, Kraljevic-Simunkovic $S$. Laser acupuncture in the treatment of burning mouth syndrome: A pilot study. Acupunct Med. 2013;31(4):453-454.

114. Arduino PG, Cafaro A, Garrone M, et al. A randomized pilot study to assess the safety and the value of low-level laser therapy versus clonazepam in patients with burning mouth syndrome. Lasers Med Sci. 2016;31(4):811-816.

115. Sikora M, Včev A, Siber S, Vučićević Boras V, Rotim Ž, Matijević M. The efficacy of low-level laser therapy in burning mouth syndrome - a pilot study. Acta Clin Croat. 2018;57(2):312-315.

116. Bergdahl J, Anneroth G, Perris H. Cognitive therapy in the treatment of patients with resistant burning mouth syndrome: A controlled study. J Oral Pathol Med. 1995;24(5):213-215.

117. Komiyama O, Nishimura H, Makiyama $Y$, et al. Group cognitivebehavioral intervention for patients with burning mouth syndrome. J Oral Sci. 2013;55:17-22. 